THE OLIVIERI SYMPOSIUM

\title{
The Olivieri debacle: where were the heroes of bioethics?
}

\section{F Baylis}

J Med Ethics 2004;30:44-49. doi: 10.1136/jme.2003.005330

All Canadian bioethicists need to reflect on the meaning and value of their work, to see more clearly how the ethics of bioethics is being undermined from within. In the case involving Dr Olivieri, the Hospital for Sick Children, the University of Toronto, and Apotex Inc, there were countless opportunities for bioethical heroism. And yet, no bioethics heroes emerged from this case. Much has been written about the hospital's and the university's failures in this case. But what about the deafening silence from the Canadian bioethics community? Given the duty of bioethicists to "speak truth to power", this silence is troubling. To date, nothing has been written about the silence. This article is intended as a partial remedy. As well, the article pays tribute to heretofore unsung heroes among Dr Olivieri's research colleagues.

Correspondence to: Professor F Baylis, Department of Bioethics and Department of Philosophy, Dalhousie University, Halifax, Nova Scotia, Canada B3H 4H7; francoise.baylis@dal.ca

Accepted 17 June 2003

\section{SCIENCE FICTION: A PROUD MOMENT IN TIME FOR CANADIAN BIOETHICS}

In late 1995 and early 1996, after six years of clinical trials, Dr Nancy Olivieri (an internationally renowned expert on blood disorders) began to have concerns about deferiprone ( $\mathrm{Ll}$ ) — a drug she was testing for the treatment of thalassaemia major. Dr Olivieri's first concern was that deferiprone might be ineffective. Later, in February 1997, she came to believe that the drug might actually be toxic: a probable cause of progression of liver fibrosis in some patients.

When she first had misgivings about the effectiveness of deferiprone, Dr Olivieri reported her concerns to Apotex Inc, the Canadian generic drug manufacturer who was sponsoring some of her research. Apotex disputed her claims about unexpected risk to patients and contested the need for her to inform patients of the "risk". Dr Olivieri told Apotex that the Research Ethics Board (REB) at the Hospital for Sick Children (HSC) (where the clinical trial was being conducted), would have to be advised of her findings regarding loss of efficacy, and that the existing protocols and consent forms would have to be modified. The REB subsequently instructed Dr Olivieri to amend the research consent forms, and also told her to report the unexpected findings to the Health Protection branch of Health Canada and to other physicians responsible for patient care who were using deferiprone.

When Apotex received the revised information and consent forms, it terminated the trial and informed Dr Olivieri that all information about the trial was to remain confidential, or there would be legal consequences. There is a comprehensive account of the details of this case. ${ }^{1-6}$

On May 24, 1996, Dr Olivieri was told: "You must not publish or divulge information to others about the work you have done with Apotex ... without the written consent of Apotex. Now, should you choose to violate this agreement you will be subject to legal action." (Thompson J, et al, ${ }^{1}$ p 144)

The HSC, where Dr Olivieri was head of the thalassaemia programme (the largest in North America), and the University of Toronto's faculty of medicine, where she held an academic appointment, were outraged at this turn of events. They immediately came to her defence and took a strong stand in support of research integrity, the protection of research participants, informed consent, academic freedom, and the protection of the public interest in the face of ever increasing pressures on universities and teaching hospitals to seek corporate sponsorship for research. They offered Dr Olivieri (and all members of staff) moral support on these matters of principle and exercised moral leadership and authority in meetings and negotiations with Apotex. Members of the bioethics department at the HSC, as well as members of the Joint Centre for Bioethics at the University of Toronto-all of whom had tried (to varying degrees) to resolve the conflict as it was brewing-actively assisted their respective institutions in defending these matters of principle. They also undertook to participate in various processes initiated to develop harmonised guidelines, policies, and procedures for corporate sponsorship of clinical research.

As well, the Canadian bioethics community at large rallied around Dr Olivieri, the HSC, the University of Toronto, and other Toronto based bioethicists. Together, they took a united stand in support of academic freedom, informed consent, the protection of research participants, and public accountability. These core ethical issues were debated at the annual meeting of the Canadian Bioethics Society, where several motions were passed, including a motion to develop clear policies and practices for sound ethical partnerships involving hospitals, universities, university researchers, and industry. Individual bioethicists were galvanised into action; there were discussions with Health Canada, the National Council on Ethics in Human Research, and the biomedical ethics committee of the Medical Research

The Health Protection Branch has since been renamed the Health Products and Food Branch of Health Canada. The Health Protection Branch was a branch of government responsible for managing risks and benefits related to health. The new organisation is responsible for managing risks and benefits related to health products and food."

All page numbers given in this paper refer to the actual printed report unless otherwise stated. ${ }^{* *}$ 
Council of Canada. As well, several articles were published in prominent professional journals, and there were a good number of public lectures and media interviews. Indeed, this was a proud moment for Canadian bioethics.

Had it been the case that all this were true... . But of course the above italicised text is fictional.

While the description of the events until the time at which Apotex terminated the trials and threatened legal action is accurate, the details about the various responses to the controversy surrounding the dispute are but a figment of my imagination. The University of Toronto did acknowledge that Apotex was acting inappropriately, and eventually did accept that it had a responsibility to defend Dr Olivieri's academic freedom. No steps were taken to meet this responsibility, however, "except for the Dean of Medicine's clearly ineffective 1996 requests to Apotex to desist". ${ }^{3}$ The hospital, for its part, took no effective action to support Dr Olivieri (Thompson J, et al, ${ }^{1}$ pp 155-8). and indeed there is good evidence that efforts were made to undermine Dr Olivieri (Downie J, et al, ${ }^{3}$ pp 108-10). As Drs Nathan and Weatherall (internationally renowned blood researchers) have written on this point: "although the Hospital for Sick Children and the University of Toronto knew that [Olivieri's academic] freedom was under attack, Olivieri received harassment instead of support from the hospital and ineffectual support from the university in her legal stand against Apotex" (Nathan DG, et al, ${ }^{6} \mathrm{p}$ 1369). See also Spurgeon D. ${ }^{7}$ For their part, bioethicists on site, and the bioethics community at large, from beginning to end, were largely silent.

In this article, I will not add to the extensive commentary arguing that the hospital and the university failed to vigorously defend academic freedom and to seriously tackle the complex issue of conflict of interest with industry/ university research partnerships. I will focus instead on the deafening silence from the Canadian bioethics communityfrom all of us in Canada whose professional work (clinical or academic) is in the area of bioethics. Given the duty of bioethicists to speak truth to power, ${ }^{8}$ this silence is troubling.

The time has come to critically examine the failure of Canadian bioethicists to play a pivotal role in this precedent setting research ethics controversy. It is important to question the meaning and value of bioethics work in clinical and academic settings, if bioethicists say and do nothing (or very little) in difficult and complicated cases that directly challenge cherished fundamental ethical standards and principles.

\section{STORIES OF SILENCE}

In 1998, as the controversy involving Dr Olivieri, the HSC, the University of Toronto, and Apotex continued to escalate, the board of the HSC mandated a review of the facts and circumstances in the controversy. Dr Arnold Naimark agreed to conduct the review. Part way through the review process, because of ongoing controversy about his perceived conflicts of interest as well as concerns about the legitimacy of a single person review committee, he appointed two associate reviewers well known to the Canadian bioethics community, Professor Bartha Maria Knoppers and Dr Frederick Lowy.

The final report of the Naimark committee, submitted in November 1998, suggests that the role of bioethics in helping to resolve the controversy was, at best, very limited. In a 160 page document, there are but a few paragraphs that discuss the role of bioethics:

Dr Buchwald [director of the HSC Research Institute] had asked Ms Mary Rowell, bioethicist, for assistance in understanding the issues involved in the controversy. On June 29, 1998, Dr Buchwald clarified the terms under which he had asked Ms Rowell to assist him. He stated: "I need to understand the perceptions of the issues by each party and their views regarding the chronology of what occurred. I asked you to determine what would be perceived as an appropriate process to resolve the issues ... and to make recommendations to me on how to proceed with the resolution... . I also asked that you be prepared to advise me regarding your view of any ethical issues that may come to light and also the process for solving them and preventing a future occurrence...".

In the latter part of August, 1998 Ms Rowell wrote to Dr Goldbloom [vice president, academic and clinical development] and Mr Strofolino [president and chief executive offier (CEO) of HSC] about the mounting controversy. She touched on the various issues and grievances that had been raised about the Apotex/Olivieri affair and outlined the steps needed to resolve the crisis. She indicated that there was considerable dismay about management's unresponsiveness and resistance to mediation of the issues. The damage being done to the reputation of the hospital was particularly worrisome.

Another noteworthy feature of the final report submitted by the Naimark committee is the absence of any comment on the roles and responsibilities of the bioethics department at HSC and the Joint Centre for Bioethics at the University of Toronto (of which the HSC bioethics department is an affiliate member). One possible explanation for this omission is that while the Naimark committee knew of Ms Rowell's involvement in the case, they did not know there was a bioethics department at HSC (and so did not contact the director, Dr Christine Harrison), and did not know of any formal affiliation agreement between the HSC and the Joint Centre for Bioethics (and so did not contact the director, Dr Peter Singer). (Neither C Harrison, director of the bioethics department at HSC, nor P Singer, director of the Joint Centre for Bioethics at the University of Toronto, are among those included in the list of contacts in the Naimark final report.)

This explanation is, however, implausible. Dr Frederick Lowy-an associate reviewer with the Naimark committeewas the founding director of the Joint Centre for Bioethics (indeed, this fact added to the original concerns about conflict of interest with the review process). Dr Lowy initiated the process that led to the HSC bioethics department becoming an affiliate member of the Joint Centre of Bioethics. As well, the other associate team member, Professor Knoppers, was very familiar with the work of the bioethics department and the Joint Centre for Bioethics. Therefore, knowledge of the scope and nature of bioethics practice within HSC and its relation to the Joint Centre for Bioethics, was available to the Naimark committee. Thus, ignorance of the bioethics resources available at HSC and the University of Toronto cannot explain the Naimark committee's failure to meet with, and report on, the contributions (or lack thereof) of the directors of the HSC bioethics department and the University of Toronto's Joint Centre for Bioethics.

A second possible explanation for this omission is that the director of the HSC bioethics department and the director of the Joint Centre for Bioethics were not involved in the case and so there was nothing on which to report. In 1999, the Canadian Association of University Teachers commissioned an independent committee of inquiry to investigate the case involving Dr Olivieri. The committee of inquiry issued its findings in 2001 and, by most accounts, this 540 page document is a more accurate, careful, and complete report of the facts and circumstances than the earlier 160 page report published by the Naimark committee. The committee of inquiry report confirms that Dr Harrison, the director of the 
bioethics department at HSC, was not involved in the case (Thompson J, et al, ${ }^{1} \mathrm{p}$ 257). This left the more junior member of the department, Ms Rowell, to deal with the issues alone. This fact is striking when one considers that Ms Rowell has reported that "she was treated so rudely by the hospital executive when she raised concerns about the Olivieri affair that she considered resigning". ${ }^{10}$ Indeed, she did eventually resign.

As for any possible involvement in the Olivieri dispute by the Joint Centre for Bioethics, the committee of inquiry concluded that "The Joint Centre, as a centre, appears not to have been engaged or to have spoken publicly on the controversy. Its silence is hard to understand" (Thompson J, et al, ${ }^{1} \mathrm{p}$ 258). Further, Dr Singer, the director of the Joint Centre for Bioethics, declined the invitation to meet with the committee of inquiry. Reflecting on this, the committee of inquiry reported:

\section{The Joint Centre for Bioethics is a partnership between the university and a number of health care institutions. Staff bioethicists of HSC and other hospitals are members of the joint centre. Its website states: "Our mission is to provide leadership in bioethics research, education, and clinical activities". The efforts by Apotex to deter Dr Olivieri from informing patients about risks she had identified, and the lack of effective support for her by HSC and the university, gave rise to one of the most significant and highly publicised bioethical disputes in Canada in many years. Yet the Joint Centre for Bioethics appears not to have provided leadership in this matter. \\ Dr Peter Singer, director of the joint centre, declined to meet with this committee of inquiry and, instead, informed us in writing that: "The involvement of the joint centre was through the work of two of its members-Dr Christine Harrison and Professor Mary Rowell-who are the Bioethicists at the Hospital for Sick Children. I understand that they have already met with you in this matter." (Thompson J, et al, ${ }^{1}$ p 257)}

Dr Singer is a senior figure in Canadian bioethics. His decision not to meet with the committee of inquiry and to remain silent is difficult to understand, especially in view of the centre's Statement of Mission, Vision, Values and Goals which states: "Our mission is to provide leadership in bioethics research, education, and clinical activities... . The JCB does not advocate positions on specific issues, although its individual members may do so". $^{\prime 1}{ }^{11}$

Ms Rowell has also chosen to remain silent and she has never publicly told her story. The closest she has come to doing so was at the 13th Annual meeting of the Canadian Bioethics Society in the fall of 2001. During the question period, after a plenary lecture entitled $A$ Reflection on the "Place" of Bioethics ${ }^{12}$ criticising the Canadian bioethics community at large for its silence on two internationally prominent ethics cases originating in Toronto-one involving Dr Nancy Olivieri, the other involving Dr David Healy ${ }^{13}{ }^{14}-$ Ms Rowell spoke passionately from the floor about the unbearable stress and lack of institutional support she experienced while involved in this case in her official capacity as bioethicist. She indicated that she had no choice but to leave her position at the hospital.

When Ms Rowell spoke at the Canadian Bioethics Society annual meeting, I was reminded of an observation made by my friend and colleague, Dr Benjamin Freedman, in his writings on bioethical heroism: "Working at the intersection between conflicting claims of patients, staff, and administration, bioethicists must often find themselves under pressure to compromise their ideals, to 'get along by going along"'.15 What pressure had Ms Rowell been under? Where had it come from? How unbearable had it been? At what point had she come to believe that she had (perhaps unintentionally) compromised her ideals? Was she living with moral residue? ${ }^{16}$

And, what about the director of the bioethics department, Dr Christine Harrison, and the rest of the Canadian bioethics community? At no time has Dr Harrison spoken publicly about her involvement in this case. It is known, however, that she did not speak publicly about the case or the issues raised by the case and furthermore that she was a member of the ad hoc subcommittee of the medical advisory committee (MAC) of the Hospital for Sick Children-the committee that advises the board of trustees on disciplinary action against staff physicians. The MAC established a fact finding subcommittee following receipt of the Naimark report. The significant limitations of the subcommittee's review are discussed in the Report of the Committee of Inquiry on the Case Involving Dr Nancy Olivieri, the Hospital for Sick Children, the University of Toronto, and Apotex Inc (Thompson J, et al, ${ }^{1} \mathrm{p}$ 336).

As for the non-response from the Canadian bioethics community at large, while initially only two members of the bioethics community, Dr Harrison and Ms Rowell, may have had intimate knowledge of the events at HSC, by the fall of 1998 there was considerable information in the public domain to which other members of the Canadian bioethics community could have responded. Only one person, however, is known to have taken up the cause: Professor Arthur Schafer, the director of the Centre for Professional and Applied Ethics at the University of Manitoba. At the invitation of Dr Olivieri and colleagues, Professor Schafer became actively involved in the controversy. He participated in news conferences and media interviews. He also participated in two fund-raising events organised by Doctors for Research Integrity to help pay the mounting legal bills of Dr Olivieri and her colleagues. For each of these events he prepared a report: Medicine, Morals and Money: the High Road or the Bottom Line (A Schafer, unpublished ms, 1998) and later Medicine, Morals and Money: Dancing with Porcupines or Sleeping beside Elephants (A Schafer, unpublished ms, 2001).

Less well known is the fact that a group of bioethicists at Dalhousie University, including myself, wrote to the president of the HSC, the dean of the faculty of medicine at the University of Toronto, and the director of the University of Toronto Joint Centre for Bioethics (copied to a number of individuals including all three members of the Naimark committee), asking them to clarify their respective institution's policies and commitments in relation to the physician/ researcher's duty to disclose risks to research participants and the freedom of bioethicists to speak out against unethical practices. In this letter we were careful not to take a position on the merits of the specific case, as not all of the relevant facts were known to us. Rather, this was a carefully worded letter with several objectives: to let these institutions know that members of the bioethics community were watching the case, to elicit certain facts relevant to our concerns, and to show support for our bioethics colleagues. We wrote:

... bioethicists have professional responsibilities that must never be compromised by the conditions of their employment. These responsibilities include preventing unethical behaviour, where possible, confronting such behaviour if it does occur, and further ensuring that measures are introduced to preclude the recurrence of unethical behaviour. These obligations may require bioethicists to advocate on behalf of persons or for a particular position on a controversial issue and, if other means have failed, to draw public attention to the matter. The institutions for 
which bioethicists work or with which they have formal affiliation must support bioethicists when they engage in debate and speak out against unethical practices, so that the professional integrity of bioethicists is not compromised (correspondence with M Strofolino, A Aberman and P Singer, 26 November 1998).

The president of the HSC, the Dean of the faculty of medicine, the director of the Joint Centre for Bioethics and others answered our letter. The response from the HSC was brief:

We are confident that the policies and practices at the Hospital for Sick Children support the integrity of research and of our bioethicists. However, we have chosen not to respond publicly on these other related issues until after $\mathrm{Dr}$ Naimark submits his report (correspondence from Mr M Strofolino, 3 December 1998).

After the Naimark report was published we sent a follow up letter to the president. This letter was referred to Dr Buchwald. His response was equally brief and he suggested we consult the Tri-Council Policy Statement on Ethical Conduct for Research Involving Humans (national guidelines for all research involving humans). Similarly, the original responses from the dean of medicine and the director for the Joint Centre for Bioethics directed us to various policy documents. None of the letters directly engaged the substance of our letter.

For complicated (and perhaps ultimately indefensible) reasons, we decided not to pursue further communication. Instead, we returned to our academic pursuits and published on the roles and responsibilities of bioethicists. In retrospect, I believe this was a mistake.

\section{UNSUNG HEROES}

Several opportunities for heroism arose in the case involving Dr Olivieri; this was an ethical struggle of international proportion calling out for someone to take a principled stand in the face of serious wrong, in order to protect the interests of research participants and the integrity of the research process. ${ }^{17}$ Where were the heroes of bioethics? (Freedman $\mathrm{B},{ }^{15}$ pp 297-9).

Some years ago, Benjamin Freedman noted that, given the nature of clinical ethics work, occasions for heroism in bioethics were plentiful and yet, there were no tales of bioethical heroism. "How could this be," he wondered. Were he alive today, Benjy would surely bemoan the fact that trained bioethicists failed to speak out publicly in this case (with the notable exception of Professor Schafer). Indeed, the heroes in this case are scientists. Dr Olivieri and a few of her research colleagues then at the HSC, Drs Helen Chan, John Dick, Peter Durie and Brenda Gallie, risked their careers, their health, and their finances to defend principles they held dear. As well, it was scientists, Dr David Nathan of the Dana Farber Cancer Institute in Boston and Sir David Weatherall of Oxford University who intervened on Dr Olivieri's behalf to broker a settlement to the ongoing dispute. Dr Olivieri's heroism and the contributions of Drs Nathan and Weatherall are well known to many. Less well known, but no less important, is the heroism of four of Dr Olivieri's colleagues. This article begins to tell some of their story.

A hero, according to Urmson, is a person who fulfils or exceeds the demands of duty in contexts where most others would fail to do so. In the face of adversity, she acts courageously in pursuit of a morally praiseworthy goal, even when this may involve or result in significant personal sacrifice. For Urmson, a person may be called a hero:
(1) if he does his duty in contexts in which terror, fear, or a drive to self preservation would lead most men not to do it, and does so by exercising abnormal self control...

(2) if he does his duty in contexts in which fear would lead most men not to do it, and does so without effort...

(3) if he does actions that are far beyond the bounds of his duty, whether by control of natural fear or without effort. ${ }^{18}$

In defending Dr Olivieri, Drs Chan, Dick, Durie, and Gallie placed the interests of others above their own interests. They took a stand in defence of the principles of research integrity, academic freedom, informed consent, and patient safety, and they did so in the face of tremendous pressure from within their workplace. See-for example, Koren reprimanded by Ontario College of Physicians and Surgeons. ${ }^{19}$ While initially they took this stand because they felt they could not do otherwise, there can be no denying that their actions required courage, "courage to take a stand in the face of serious wrong, and courage to persevere in the face of seemingly constant 'setbacks, weariness, difficulties and dangers"'. ${ }^{20}$ Courage was required not only to take the initial stand, but also to persevere as the HSC became much more aggressive in its public denunciations. Dr Olivieri's supporters not only faced increasing hostility from the HSC, but also a loss of support from colleagues who turned away because of the hospital's actions.

\section{Research integrity}

A central issue in this case was conflict of interest. It was well known at the time of the dispute, and subsequently well documented, that Apotex and the University of Toronto were discussing a multimillion dollar donation to the university for the construction of a new biomedical research centre $(\$ 20$ million to the university and $\$ 10$ million to the university's affiliated teaching hospitals). This promise of new funding (which was to be matched by other sources for a total of approximately \$92 million) (Thompson J, et al, ${ }^{1}$ p 94) put the institution in an ethically troubling conflict of interest situation (dependence on corporate funding introduces both pressures and temptations):

If realised, this would have been the largest corporate donation ever received by the University. While these negotiations were ongoing, the then University of Toronto president, President Prichard, at the request of Apotex, wrote to Prime Minister Chretien and four other federal ministers regarding proposed drug patent regulations. He wrote that Apotex had: "promised 'a very substantial philanthropic commitment' to the university. He went on to say that Apotex 'has advised us that the adverse effect of the new regulations would make it impossible for Apotex to make its commitment to us'. Prichard urged the Prime Minister and Liberal cabinet members to do what is necessary 'to avoid the serious negative consequences to our very important medical sciences initiative'." (Thompson J, et al, , p 99)

President Prichard later apologised to the Executive Committee of the University for this action, acknowledging that he had made "a mistake" and that the letter had "placed the University in an inappropriate position of intervening in a matter beyond the legitimate scope of the University's jurisdiction" (Thomson J, et al, p 100, in: Gibson $\mathrm{E}$, et al, ${ }^{4}$ p 448).

As I and others have argued elsewhere, objectivity and integrity can be put at risk through industry/university partnerships: 
The duty of universities is to seek truth. The duty of pharmaceutical companies is to make money for their shareholders. Drug companies that fail to do so go out of business. Universities that subordinate the disinterested search for truth to other ends lose credibility and their claim to a privileged status in society. If either abandons its fundamental mission, it ultimately fails. At times, institutional imperatives are bound to conflict. (Lewis $S$, et al, ${ }^{21}$ p 783)

When institutional imperatives conflict, there have to be clear mechanisms in place to protect the interests of patients and the essence of academic inquiry against the legal and financial power of the pharmaceutical industry. There were no such mechanisms at the HSC. In this policy vacuum, Dr Gallie set out to educate the HSC administration about events involving Dr Olivieri. She argued that the approach taken by Dr Olivieri-to report her concerns to the REB and, following their instructions, to modify the consent forms, and advise physicians outside HSC of the changes-was consistent with "normal clinical trial methodology where great caution is exerted to prevent harm to those people who volunteer for clinical trials" (correspondence with M Buchwald and M Strolofino 12 May 1998; correspondence with M Buchwald and M Strofolino 3 June 1998). In contrast, the approach taken by Apotex, which involved terminating a clinical trial because the data suggested a lack of effectiveness or toxicity, was not consistent with normal clinical trial methodology and appeared to be motivated primarily by commercial interests.

Similar concerns were brought to the attention of Dr Buchwald, the director of the HSC Research Institute, by Dr Dick. Dr Dick pointed out that: internationally renowned leaders in the field of blood research were dismayed at what was happening at HSC. When a researcher of Dr Olivieri's stature identifies a serious research risk he argued, the institution has a responsibility to ascertain and assess the potential risk to clinical trial participants, and then to act accordingly.

Drs Chan, Dick, Durie, and Gallie sought to defend the integrity of the research process and to insist that the interests of patients should outweigh any commercial or other interests that Apotex or the hospital might have.

\section{Academic freedom}

The principle of academic freedom (to publish findings or publicly voice opinions) was also central to this case. The freedom of academics to share their views, even when these views are unpopular and potentially threaten their institution's commercial interests is the hallmark of academia. It ought not to have been difficult for anyone (let alone those who claim expertise in ethics), to have stood tall and firm in support of this fundamental principle, especially because of the potential beneficial impact of publication of the research results. With publication, research findings can be tested by peers. The findings can then be confirmed or disputed, thereby contributing to knowledge production and eventual benefit for both patients enrolled in the clinical trials of Ll, as well as other thalassaemia patients with an interest in the outcome of the research. Defending academic freedom did not require taking a stance on whether Dr Olivieri was right or wrong in her assessment of the efficacy of deferiprone, it merely required defending her right to present her views to her scientific peers.

In taking up Dr Olivieri's cause, Drs Chan, Dick, Durie, and Gallie never sought to defend any of the specific claims made by Dr Olivieri regarding the efficacy or safety of deferiprone. None of them had the expertise to evaluate the science and determine whether Dr Olivieri's claims were right or wrong.
Rather, they sought to defend the scientific method whereby researchers present their findings at scientific meetings and in scientific journals, so that these findings can be critically evaluated by peers as part of the ongoing process of gathering the best evidence on which to base clinical care. Early in the dispute, in keeping with the commitment to scientific integrity, there were efforts to initiate an internal review of the science by scientists appropriately qualified to judge the research findings. These efforts were not successful. At any rate, the principle at stake in this case, and the principle defended by Drs Chan, Dick, Durie, and Gallie, was the right of a scientist to present her findings for peer review.

\section{Informed consent and patient safety}

It is widely accepted in North America and clearly documented in the Tri-Council policy statement ${ }^{22}$ (the guidelines that govern research involving humans in Canada), that research involving humans cannot proceed without prior review and approval by a research ethics board. One of the responsibilities of the research ethics board is to ensure that there is a favourable harm/benefit ratio and that adequate provisions have been made for the informed consent of research participants. Also non-controversial is the fact that a legally and morally valid consent requires full disclosure of relevant information, including information about possible harms and benefits. This information is to be updated as new information becomes available, and at all times consent is revocable. Indeed, the ongoing right of research participants to be informed of potential research risks and the correlative ongoing duty of researchers to inform participants of such risks is uncontested in Canada.

All of Dr Olivieri's supporters were outspoken advocates of informed consent and the safety of child research participants. As Dr Durie said, "This is really about children who undergo clinical trials and their safety and their interests and the responsibility of the institution toward them". ${ }^{23}$

Dr Brenda Gallie, then head of the Research Program of Cancer and Blood at HSC (and as such Dr Olivieri's immediate administrative leader on the research side), was deeply concerned about consent issues and potential harm to children. On behalf of Dr Olivieri, she lobbied the administration at HSC to recognise and safeguard its fiduciary relationship with patients and research participants. She insisted that the safety and wellbeing of child research participants must come before "all other concerns, including institutional loyalty".23

\section{OF RISKS AND CONSEQUENCES}

As documented above, Drs Chan, Dick, Durie, and Gallie took a principled stand in support of research integrity, academic freedom, informed consent, and patient safety. For this, they each paid a heavy price. There were serious consequences for themselves, for their partners, and for their families. Personal and professional relations were strained, respect and trust among colleagues was seriously threatened, and self confidence was undermined. As well, there were serious health consequences for some, owing to the incredible stress they were under as they were attacked or shunned by colleagues at HSC and the University of Toronto. In addition to such personal costs, there were also significant financial costs-for example, lawyers' fees and disbursements.

The professional costs have been no less significant. Dr Gallie's research in retinoblastoma is of international renown and has most recently been celebrated in a national special exhibition "The Geee! in Genome" that opened in the nation's capital on April 25, 2003. ${ }^{24}$ She feels that her outspoken determination in the Olivieri case has limited both her opportunity for advancement and the application of her research findings to improve the health of children. Most 
importantly, she also believes that because of her involvement in the Olivieri case, HSC has disregarded her research findings on molecular diagnosis of retinoblastoma mutations (B Gallie, personal communication 2003) and denied children and families with, or at risk of, retinoblastoma timely access to more sensitive, more efficient, and less costly testing. ${ }^{25}$

Finally, it is important to note the opportunity costs. The energy directed to resolving this controversy by these four eminent researchers was energy not directed to their respective ongoing research programmes. In each of these areas one must ask the following questions: How much research was not done? How many research papers were not written? How many students' educational experiences were compromised? And, most importantly, what has all of this meant in terms of possible delays in the advancement of knowledge in pursuit of the care for children? The following example serves to illustrate the point.

At the time the Olivieri controversy was brewing, Dr Dick and his research team had just recently discovered a novel and unexpected class of blood stem cells. They published their findings in the summer of $1998,{ }^{26}$ but were not able to capitalise on this discovery. Dr Dick experienced several serious health problems during his involvement in the Olivieri case. Many believe these problems were a direct consequence of his involvement in the case. Clearly it is impossible to prove that there was a cause and effect relationship, but it is fair to say that stress is generally detrimental to one's health. When Dr Dick returned to work after a health related absence, he found it very difficult to carry on his research with his usual drive and determination. Compounding this problem was his reluctance to hire new staff because he felt it would be unfair to bring new people into a suboptimal work environment. Without new staff, the research team could not move its initial discovery forward, and others have since filled the vacuum. He has recently left HSC to take a leadership role in building a stem cell programme at the University Health Network.

\section{NO PLACE FOR NEUTRALITY}

At the end of the day, it is certainly a good thing that researchers were front and centre in the ethical struggle for the protection of research integrity, academic freedom, informed consent and patient safety. But it is also surely deeply problematic that, for the most part, trained bioethicists were on the sidelines and not at their sides. In this case, bioethicists in Canada did not stand for, stand with, or even stand behind those who were taking a principled stand at great personal and professional risk. Rather, we stood aside.

It is also important to note here that at no time during this longrunning controversy has there been serious and sustained open debate and discussion about this case (and specifically the role of bioethics) through the Canadian Bioethics Society (CBS). This is not a mere oversight. In 1997, early in the controversy, I proposed to the CBS annual meeting planning committee that we have a plenary session on this topic. The suggestion was not taken up. In sharp contrast, there was a panel discussion on "Company Secrets, Patients' Health, and Bioethicists' Responsibilities: When Corporate Sponsors Hide Information" at the 1998 meeting of the American Society for Bioethics and Humanities. The presentations and discussion focused on the cases of Dr Olivieri and Dr David Kern of Brown University Medical School.
Bioethicists in Canada failed Dr Olivieri and her colleagues at HSC. Why? Did they fear losing their jobs? There are few bioethicists who have the security of tenure. Did they fear being sued? Many of the individuals and organisations involved in this case had shown themselves willing to engage in litigation. Did they fear loss of reputation? Again, many involved in this case had shown themselves willing to make damaging public comments. Did they fear retribution and consequent damage to their careers? After all, bioethics in Canada is a very small and fractured community. I do not know the reason(s) for the ensuing silence. I do know, however, that by and large Canadian bioethicists failed to speak up when there was ample time and opportunity. As a responsible community, we must ask ourselves whether we could and should have done more.

\section{REFERENCES}

1 Thompson J, Baird P, Downie J. Report of the committee of inquiry on the case involving Dr Nancy Olivieri, the Hospital for Sick Children, the University of Toronto and Apotex Inc. Toronto: CAUT, 2001. www.dal.ca/ committeeofinquiry (accessed 24 Nov 2003).

2 Baird P, Downie J, Thompson J. Clinical trials and industry. Science 2002;297:2211.

3 Downie J, Baird P, Thompson J. Industry and the academy: conflicts of interest in contemporary health research. Health Law J 2002;10:101-20.

4 Gibson E, Baylis F, Lewis S. Dances with the pharmaceutical industry. CMAJ 2002; 166:448-50.

5 Litman M, Sheremata L. The report of the committee of inquiry on the case involving Dr Nancy Olivieri: a fiduciary law perspective. Health Law Review 2002;10:3-13.

6 Nathan DG, Weatherall DJ, Academic freedom in clinical research. N Engl J Med 2002;347:1368-71.

7 Spurgeon D. Report clears researcher who broke drug company agreement. BMJ 2001;323:1085.

8 De Vries R. Why I am not a bioethicist. Bioethics Examiner 2002;6:1-4.

9 Naimark A, Knoppers BM, Lowy FH. Clinical trials of L1 (deferiprone) at the Hospital for Sick Children: a review of facts and circumstances. 1998:89-90. http://www.sickkids.on.ca/Ll trials/revcontents.asp (accessed 24 Nov 2003).

10 Valpy M. Salvage group tackles Sick Kids' image disaster. Globe and Mail 1988 Nov 2:A9.

$11 \mathrm{http}: / / \mathrm{www}$.utoronto.ca/jcb/main.html (accessed 3 Oct 2003).

12 Baylis F. A reflection on the "place" of bioethics. Canadian Bioethics Society, 13th Annual Meeting and Conference, Winnipeg, Manitoba, October 11-14, 2001. http://www.bioethics.ca/english/am/baylis2001/cbs2001b2.ppt (accessed 24 Nov 2003).

13 Birmingham K. Dark clouds over Toronto psychiatry research. Nat Med $2001 ; 7: 643$.

14 Charlton B. The David Healy affair. http://www.pharmapolitics.com (accessed 30 Apr 2003).

15 Freedman B. Where are the heroes of bioethics? J Clin Ethics 1996;7:297-9, at 298.

16 Webster G, Baylis F. Moral residue. In: Rubin S, Zoloth L eds. Margin of error: the ethics of mistakes in the practice of medicine. Hagerstown, MD.: University Publishing Group, 2000:217-30.

17 Baylis F. Heroes in bioethics. Hastings Cent Rep 2000;30:34-9

18 Urmson JO. Saint and heroes. Reprinted in: Poiman LP, ed. Moral philosophy: a reader. Indianapolis, IN: Hackett Publishing, 1993:223-31.

19 CAUT Bulletin. http://www.caut.ca/english/bulletin/2003_sep/news/ koren.asp (accessed 25 Sept 2003).

20 Baylis F. A profile of the health care ethics consultant. In: Baylis F, ed. The health care ethics consultant. Totowa, NJ: Humana Press, 1994:35.

21 Lewis S, Baird P, Evans RG, et al. Dancing with the porcupine: rules for governing the university-industry relationship. CMAJ 2001;165:783-5.

22 Medical Research Council of Canada, Natural Sciences and Engineering Research Council of Canada and Social Sciences and Humanities Research Council of Canada. The Tri-Council policy statement. Ethical conduct for research involving humans. www.pre.gc.ca/english/pdf/ TCPS\%20June2003E.pdf (accessed 24 Nov 2003).

23 Hospital for Sick Children. Media perceptions vs review findings [memo]. Toronto: Hospital for Sick Children, 1998.

$24 \mathrm{http}: / /$ nature.ca/exhibits/genome_e.cfm (accessed 30 Apr 2003).

25 Richter S, Vandezande K, Chen N, et al. Sensitive and efficient detection of $\mathrm{RB} 1$ gene mutations enhances care for families with retinoblastoma. Am J Hum Gen 2003;72:253-69.

26 Bhatia M, Bonnet D, Murdoch B, et al. A newly discovered class of human hematopoietic cells with SCID-repopulating activity. Nat Med $1998 ; 4: 1038-45$. 